\title{
Manufacturing the raw in design pageantries: the commodification and gendering of Brazilian tropical nature at the 1867 Exposition Universelle
}

Original Article for the Special Issue on Environmental Histories of Design

Word Count: 8,044

\begin{abstract}
Summary
In this article I interrogate the complex relationship between nature and culture by examining how tropical nature and raw materials were conceptualised and displayed in the nineteenth century. I do so by discussing a display of tropical wood mounted by the Empire of Brazil for the Exposition Universelle in Paris in 1867. The reception of this display in Europe is analysed through Karl Max's ideas on the gendering of nature and commodity exchange, through the concept of tropicality, and Claude Lévi-Strauss' raw and cooked binaries, which help unveil how natural materials were conceptualised and commodified into things themselves. Broadly, I am interested in putting 'nature in our official past' and bring to the fore key concerns from environmental history studies to bear upon design historical enquiries.
\end{abstract}

Keywords: Raw Materials; Tropical Nature; Brazil; International Exhibitions; Karl Marx; Claude Lévi-Strauss

\section{Introduction (why environmental history?)}

Material culture scholars and design historians, despite focussing on objects and the material and symbolic processes behind their manufacture and consumption, have shied away from tackling the issue of the commodification of natural materials and their conceptual and practical transformation into 'raw materials', 'natural resources' or 'national resources'. Tim Ingold has fiercely critiqued the emphasis these scholars place on 'materiality' as a concept, and has proposed that this emphasis inhibits our understanding and deeper explorations of materials and the natural world: 'Could not such engagement - working practically with materials - offer a more powerful procedure of discovery than an approach bent on the abstract analysis of things already made? What academic perversion leads us to speak not of materials and their properties but of the materiality of objects? It seemed to me that the concept of materiality, whatever it might mean, has become a real obstacle to sensible 
enquiry into materials, their transformations and affordances. ${ }^{1}$ Espousing Ingold's provocation I add that material culture scholars and design historians know little about how natural materials can be 'things' in themselves before becoming manufactured, designed objects. For example, despite the centrality of natural materials to the success of International Exhibitions, Expositions Universelles and World's Fairs, the scholarship on exhibitions lack a substantial critique of why and how natural materials were conceptualised, displayed and commodified in these festivals. ${ }^{2}$ What happened to natural materials before they became fully-fledged designed things and while they were promoted in the context of international exhibition, or 'design pageantries'? I call exhibitions 'design pageantries' after Werner Plum's use of the term pageants to frame these festivals as spectacles of social and cultural change. ${ }^{3}$ Here, the term 'design pageantries' will remind us that these spectacular and elaborate ceremonies privileged the display of manufacturing processes and designed objects, an angle also favoured by the specialist scholarship on the subject. ${ }^{4}$ In turn, 'design' is a term employed multifariously as a method of making and conceptualisation with forethought, as a mode of knowledge production, and an academic discipline.

Adopting some of the preoccupations and approaches of environmental historians can help material culture scholars and design historians address and contribute to our understanding of natural materials, their 'transformations and affordances', beyond the boundaries of materiality. As posited by McNeill, Pádua and Ranharajan in Environmental History: As if Nature Existed 'environmental history maintains that nature [...] is an integral part [to human affairs], one that evolves and changes just as culture does. Indeed, environmental history, while different in different hands, is always about the change in relations between societies and nature. ${ }^{, 5}$ In this vein, here I interrogate the complex relationship between nature and culture by examining how nature and raw materials were conceptualised and displayed in design pageantries. In short, I aim to investigate the changing 
nature of the idea of nature. The environmental issues discussed concern the extraction of tropical woods from the Brazilian Amazon region, their commodification, the conceptualisation of tropical nature by contemporaries in the 1860 s, the ascription of value to these materials and to the exhibition commissioners who displayed them. I have chosen the Exposition Universelle held in Paris in 1867, apart from further reasons discussed below, because this is a historical moment rarely acknowledged by studies of the environment from a design perspective. Yet, this is a rather rich period of investigation for environmental history studies, especially when Latin America is considered. ${ }^{6}$ More broadly, I question how values are ascribed to nature through design acts (i.e., methods of making and conceptualisation with forethought), how these values change over time, and how natural materials become 'raw materials', 'natural resources' or 'national resources' depending on the value system in place.

In these broader terms, I espouse the idea of nature being a construct of culture as much as culture is a construct of natural processes and phenomena. ${ }^{7}$ This principle echoes Elinor Melville's definition of environmental history as 'the study of the mutual influences of social and natural processes ${ }^{8}{ }^{8}$ However, I acknowledge that historical actors might not have framed this complex relationship in this way. During the period of global capitalist expansion in the nineteenth century, nature was conceptualised as a phenomenon to be separated from and debased in relation to culture, as I discuss below. Thus, how may current material culture scholars and design historians render nature a level of agency usually conceded to social and cultural processes whilst accepting that nature might been devoid of agency within design discourse? A way of addressing this question lies in environmental historian Shaun William Miller's call: 'the work of environmental history is to recover, in a sense, what has been lost, and to make it dear to our historical consciousness. Only by putting nature in our official past can we potentially grasp its substantially altered place in our present and future.'9 
To put nature in our official past, present and future, I have structured this article to offer a summary of Brazilian participation in exhibitions before moving on to discuss the Exposition Universelle held in Paris in 1867, the rise of global capitalism and raw material's place in its expansionist project. Through a discussion of Brazil's display of a tropical 'virgin forest', its reception in Europe and status in the world of capitalist commodity exchange, I demonstrate how this particular display challenged an established visual grammar about the tropics and how the idea of 'raw' was designed and manufactured through the manipulation of value binaries.

\section{Eurocentrism versus universality at the Exposition Universelle of 1867}

Brazil's history of participation in International Exhibitions is rich but until recently

understudied. ${ }^{10}$ Politically organised as a parliamentary monarchy until 1889 , the Empire of Brazil attended these festivals to negotiate its sovereignty and status as a progressive, civilised nation after its independence from Portugal in 1822. From the 1860s until the overthrow of the Brazilian Empire in 1889 and the fall of the First Republic in 1930, members of the Brazilian political, economic and cultural elites made intense use of exhibitions to negotiate and display their views on what Brazil was and how it should progress. Exhibitions became prime sites for the promotion of national unity and identity, at home and abroad, given the pressing necessity to establish cohesion for Brazil's immense territory and heterogeneous population. ${ }^{11}$

In 1861, the Empire of Brazil accepted an invitation to join the International Exhibition of London in the following year. Since this first official representation until its fourth appearance at the Centennial International Exhibition in Philadelphia in 1876, Brazilian imperial exhibitions were a matter of the state. Participations were financially supported by it and organised by politicians, museum directors, artists and scientists closely 
linked to the government and personally associated to the emperor. Four national exhibitions $(1861,1866,1873$ and 1875) were organised in Rio de Janeiro, the imperial capital, as preparation for respective international exhibitions (London, 1862; Paris, 1867; Vienna, 1873 and Philadelphia, 1876). Brazil's appearance in the Exposition Universelle of 1889 was organised by a privately run Franco-Brazilian syndicate. This exhibition, though, marked the end not only of imperial festivals but also of the Brazilian Empire altogether. On 15 November 1889 , a military coup overthrew the monarchy and instated a new federative Republic, the United States of Brazil. The republicans' keenness to internationally exhibit and establish their views of Brazil paralleled that of the Empire and the Brazilian First Republic was represented in several of the festivals in late nineteenth- and early-twentieth centuries. $^{12}$

Albeit rich, the history of Brazilian participation in exhibitions has not been explored from the viewpoint of environmental history. This is specially noteworthy and problematic since Brazil has exhibited mostly raw materials - extracted or cultivated - and displays of tropical nature. Moreover, for an analysis of the conceptualisation and display of nature and raw materials in design pageantries, the Paris exhibition of 1867 serves as an early moment in the Empire of Brazil's exhibitionary efforts when the nation's raw materials began to draw international attention, as I discuss in detail below. For the recently independent Empire of Brazil aspiring to position itself in the increasingly competitive international market as a raw materials exporter for European industries no better opportunity existed to test the usefulness of Brazilian nature (i.e., nature that fell within the political boundaries of Brazil) at a pageantry held in the city Walter Benjamin called the capital of the nineteenth century. ${ }^{13}$

Brazil was represented in 1867 by a team of exhibition commissioners comprised of aristocrats such as the Barão do Penedo (Francisco Inácio de Carvalho Moreira) and Visconde de Barbacena (Felisberto Caldeira Brant) plus a cadre of professional men from key 
nation-building institutions: from the National Museum to the Imperial Academy of Fine Arts and Brazilian consulates in Europe. Júlio Constâncio de Villeneuve, a prominent journalist in Brazil and commercial representative in Switzerland headed the executive committee. The committee counted with the expertise of Manoel de Araújo Porto-Alegre, João Martins da Silva Coutinho and Manoel Ferreira Lagos, among others sent to Paris under the auspices of Brazil's emperor, don Pedro II. As discussed further down, the Empire of Brazil sent a sizeable representation to this exhibition with the explicit aim of increasing commercial relations with Europe and attracting immigrants from the old continent to 'colonise' this vast country. $^{14}$

The Exposition Universelle of 1867, the second international exhibition held in France, was masterminded by Napoleon III to out-do the London festivals of 1851 and 1862 in the ongoing rivalry between Britain and France. ${ }^{15}$ Its main exhibition palace, the Palais $d u$ Champs de Mars, and environs housed more than 50,000 exhibitors from not only Great Britain, United States and Prussia but also from geographies little represented before as Japan and Latin America. ${ }^{16}$ Demonstration of colonial power marked this festival. French colonial displays had become larger, more costly to create and exotic than before, and for the first time colonised peoples were shown in tableaux-vivants of Egyptian bazaars, Tunisian barber shops and 'various cafés staffed with imported waiters and chefs' (Figure 1). ${ }^{17}$ 


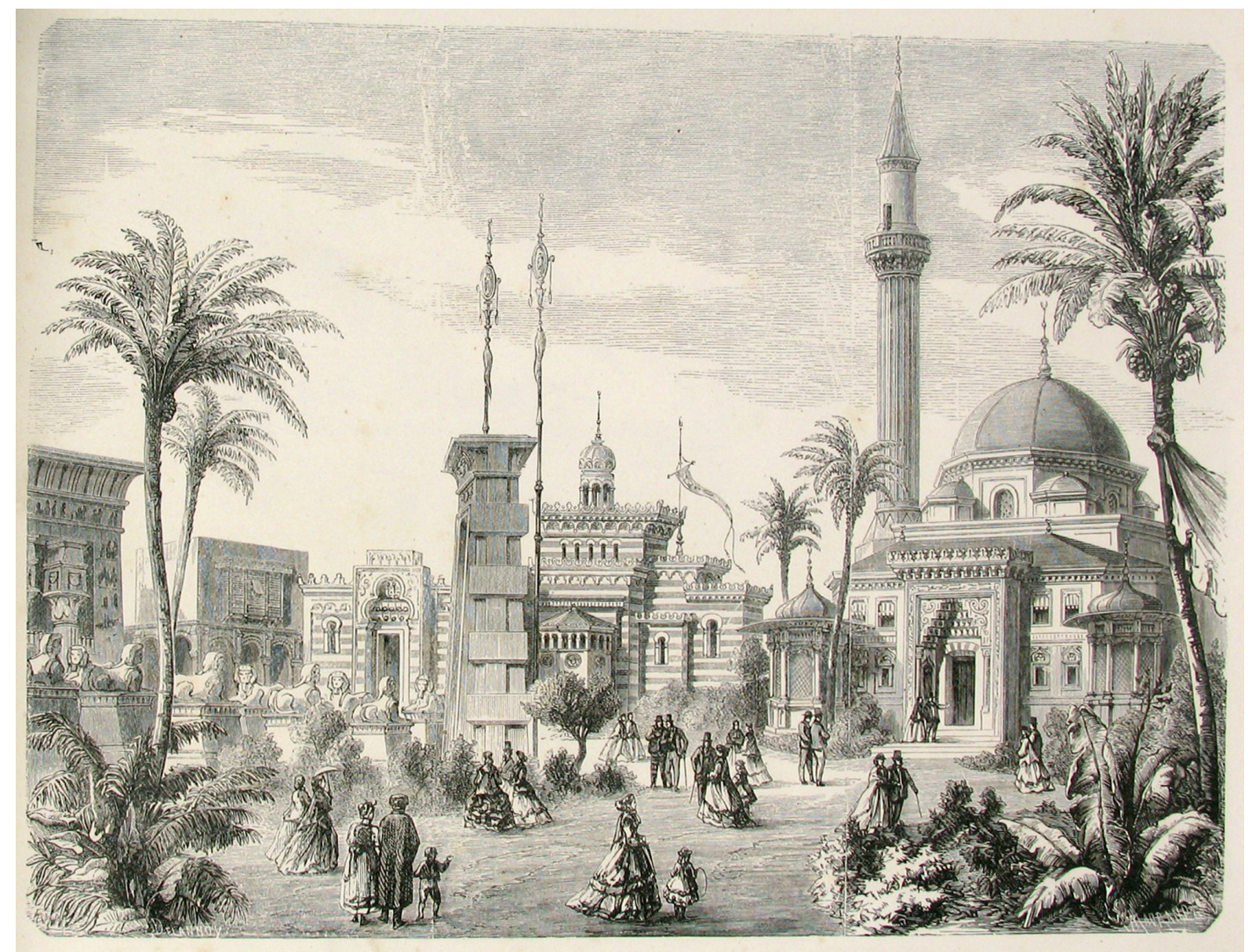

Figure 1. Lithographic drawing depicting architectural Orientalism and French colonies at the Exposition Universelle, Paris, 1867. Grand Album de L'Exposition Universelle, 1867: 150 Dessins Par Les Premiers Artistes de la France et de l'Etranger, Michel Lévy Freres, Paris, 1868. Author's own photograph 
Characterised in the literature as a 'big step forward' in exhibitionary terms and as the French Empire's 'swan song' before its defeat in the Prussian war, the Exposition Universelle of 1867 features in historical materialism accounts as an event aiming to dissipate class struggle and ameliorate social dissatisfaction by convincing poor people and labourers of the virtues of capitalism. ${ }^{18}$ It was this Exposition Universelle that prompted Benjamin to frame international exhibitions as 'places of pilgrimage to the commodity fetish"19:

The phantasmagoria of capitalist culture attained its most radiant unfurling in the World Exhibition of 1867. The Second Empire was at the height of its power. Paris was confirmed in its position as the capital of luxury and fashion. Offenbach set the rhythm for Parisian life. The operetta was the ironical utopia of a lasting domination of capital. ${ }^{20}$

In the same year Marx first published Das Capital, the festival's organisers wished to promote 'social peace' by offering the 'less fortunate' the promise that material improvement was attainable by all. ${ }^{21}$ Whilst Marx predicted that a proletarian revolution would overthrow capitalism, exhibition organisers favoured the display of objects and housing systems designed for the consumption of low-income labourers, winning workers' consent and absorbing them as consumers into the capitalist economic system. ${ }^{22}$ The 'radiant unfurling' of capitalist culture, however, was not exclusive to France in the 1860s. In different but no less 'lasting' form, the Paris festival contributed to the unfurling of capitalist culture in nations like Brazil. The Exposition Universelle wanted to be 'universal', as its name testifies, and one of the facets of this universality was the unobstructed expansion of capitalism.

The Exposition Universelle's wishful universality was constructed in many forms. In material terms, the 'design for the poor' objects inscribed the labour classes into the expansion of consumerism, at least theoretically, already enjoyed by other classes. ${ }^{23}$ In geopolitical terms, the erection at the exhibition park of hundreds of pavilions, cafés and eateries typically representing other nations and French colonies wished to promote the idea that all peoples gathered in Paris (Figure 1). The French capital, therefore, was not only the 
'capital of luxury and fashion' but also the capital of the planet. Finally, in historical terms, the Exposition Universelle attempted at a universalising reorganisation of time offered by its 'History of Labour' special exhibition. This display 'showed the various phases through which each country had passed before arriving at its present state of civilization' ${ }^{24}$ By historicising human endeavour over an evolutionary scale of productivity whose apex was industrialisation, French exhibition organisers argued for European superiority. Conversely, this historical perspective demoted non-industrialising nations to a lesser degree of evolution on that scale. Below, I discuss how the Brazilian Empire, an agrarian and raw material producing nation, circumvented the conflict imposed by this Eurocentric view of the world. Inside the Palais du Champs de Mars, another type of Eurocentric universalism was embraced. The premise that the French possessed and diffused universal knowledge was tested in the design of the edifice built to organise the exhibits in tandem with the classification system devised to order their display. 'The crowds were to be educated not by selective instruction', asserts Paul Greenhalgh referring to previous exhibitions based on object lessons, 'but by the presentation of every aspect of existence in one spectacular edifice'. ${ }^{25}$ The exhibition palace, a one mile-wide oval building, was designed to house objects from around the world under an alleged comprehensive classification. The classification system, a hallmark of the 'encyclopaedic ambitions of the Second Empire', ordered exhibits following two simultaneous principles: class and provenance. ${ }^{26}$ Under class, objects were grouped according to material qualities, function, and/or utility. The second principle grouped objects according to provenance and imparted a sense of 'nationality' to them. This dual system, mirrored in the physical disposition of nations and objects in the building, was designed to encourage visitors to compare similar classes of objects produced by different nations and judge what nations excelled in production. 
Despite their intended design, or because of it, the edifice and the classification system proved flawed before the exhibition opened. Villeneuve, the chief Brazilian exhibition commissioner, reported to the Brazilian emperor that the French classification system was inadequate for ordering the Brazilian exhibits. He noted that the "methodical division adopted by the French Commission, extremely ingenious and effortless for the industrial nations, presents serious inconveniences to the essentially agrarian countries, whose products, like ours, consist above all of raw materials' ${ }^{27}$ Brazilian commissioners were not alone in feeling these classificatory inconveniences as displays of raw materials abound in the exhibition palace, albeit with different connotations. In Australian and Canadian quarters, raw materials were deployed to justify British colonial assimilation and exploitation (Figure 2). In the exhibitions of ascending regions like Prussia, raw materials from their own territory were flaunted as signs of power. These European raw materials were often presented in large and sophisticated displays, exhibited close to technological advances from the 'old continent'. Prussia caused a stir by displaying the immense steel Krupp cannon (Figure 3), one of the most powerful and destructive designs in the world, while also showing a large display of salt cut into blocks and arranged as a cave at the centrepiece of a strong exhibitionary composition topped by the Kingdom of Prussia eagle (Figure 4$).{ }^{28}$. The salt cave was flanked by two columns of charcoal arranged in the most typical technique of display used for raw materials in exhibitions, the trophy. 


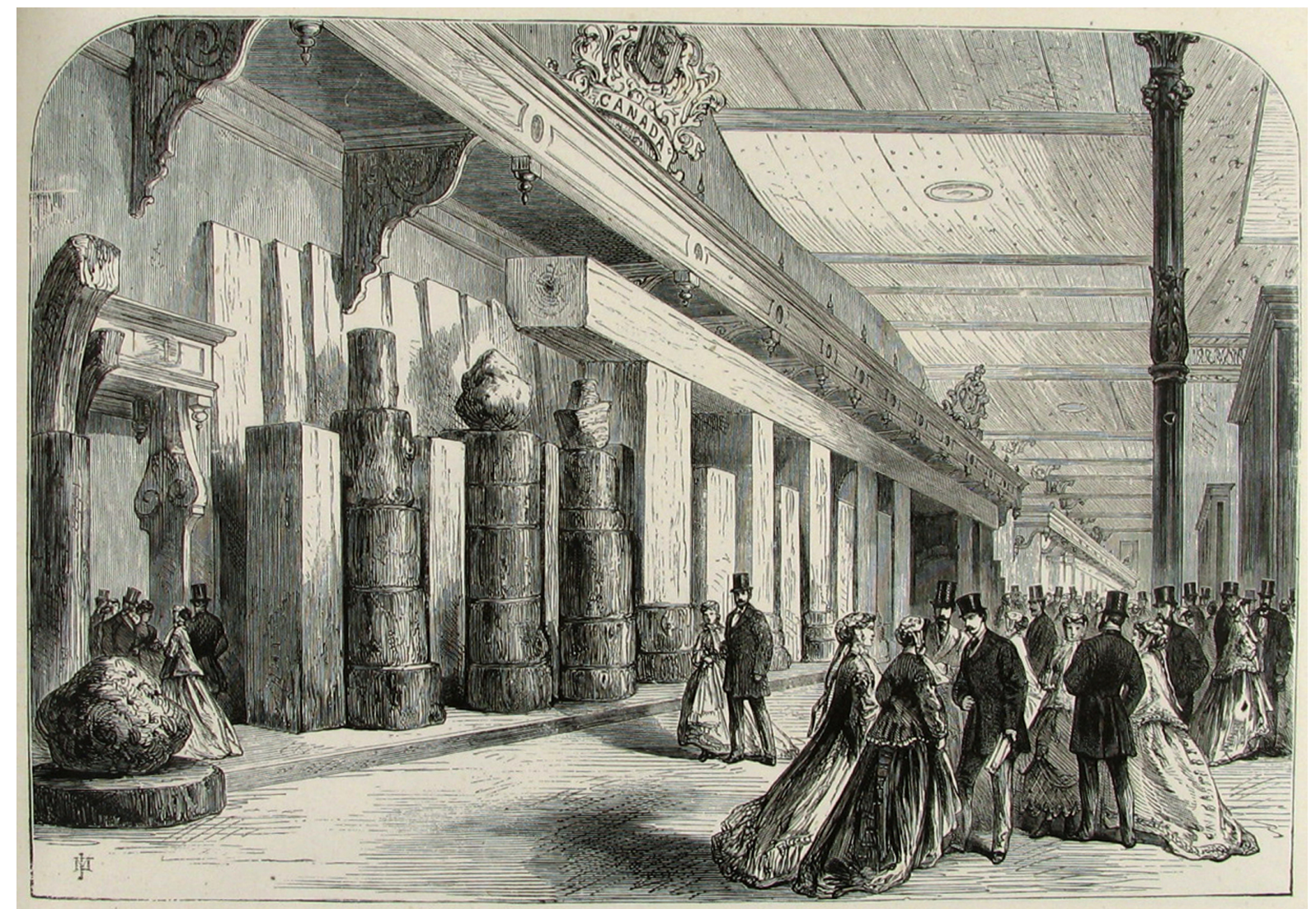

Figure 2. Lithographic drawing depicting the display of timber from Canada exhibited at the British colonial court, Exposition Universelle, Paris, 1867. Grand Album de L'Exposition Universelle, 1867: 150 Dessins Par Les Premiers Artistes de la France et de l'Etranger, Michel Lévy Freres, Paris, 1868. Author's own photograph 


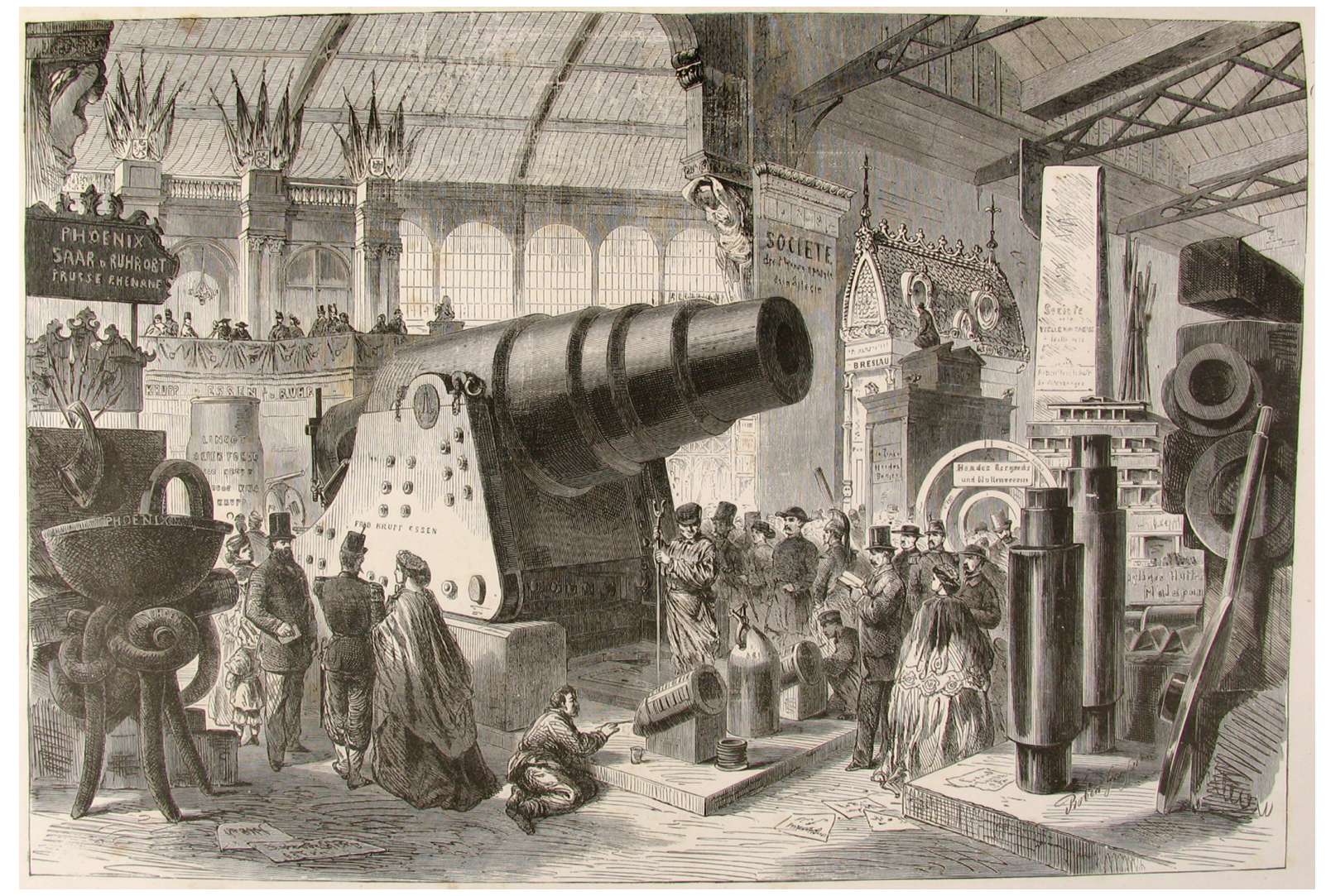

Figure 3. Lithographic drawing depicting the Krupp Cannon exhibited by Prussia at the Exposition Universelle, Paris. Grand Album de L'Exposition Universelle, 1867: 150 Dessins Par Les Premiers Artistes de la France et de l'Etranger, Michel Lévy Freres, Paris, 1868. Author's own photograph 




Figure 4. Lithographic drawing depicting Prussia's display of salt and charcoal at the Exposition Universelle, Paris, 1867. Grand Album de L'Exposition Universelle, 1867: 150 Dessins Par Les Premiers Artistes de la France et de l'Etranger, Michel Lévy Freres, Paris, 1868. Author's own photograph 
Typically, the trophy consisted of three-dimensional volumes of real or fake raw materials stacked high in a quasi-pyramidal form. In some instances, as in the Prussian case, the trophy acted as an index of reality as the fake coal blocks corresponded to the actual volume of charcoal extracted from Prussian mines. In the literature about exhibitions, however, trophies are mostly associated with colonial displays of raw materials and placed in opposition to displays of industries and so-called 'civilisation'. ${ }^{29}$ Exhibition scholar Pieter Van Wesemael insists on this oppositional premise when discussing differences in architectural forms of national displays at the Exposition Universelle:

\begin{abstract}
Where the highly industrialised countries were presented in a fictive-historical national style, the less developed countries were immersed in authentic, indigenous architecture. [...] Colonies apparently had no culture of their own, they had been designed as a trophy of products, the symbol of the country's natural wealth instead of its civilization. For example, the Canadian façade consisted of one long trophy of wood. The Australian one was comprised of a kind of triumphal arch made of wool and maps of the most important wool sheep-farming areas, crowned by stuffed ostriches, kangaroos, and the flags and insignia of the colony. The trophy that, in 1851, had been simply stacked to form a pillar had now grown to form complete façades and rooms. ${ }^{30}$
\end{abstract}

Despite his astute observation on the evolution of techniques of display, Wesemael's interpretation is challenged by further research into how raw materials have been negotiated at exhibitions. As seen in the Prussian case, raw materials were not always shown in opposition to 'civilisation' while 'less developed' or industrialised countries like Brazil (neither a colony or colonised in 1867) were not immersed in indigenous architecture either. In fact, power was located, in exhibitions and outside them, precisely in the possibility of possessing raw materials and the markers of civilisation, an argument to be developed in the paragraphs below.

\title{
Gendering nature and manufacturing the raw in design pageantries
}

The Brazilian empire was represented by more than 3,500 exhibits of all 'classes' in Paris, from coffee beans to leather goods, from cotton pods to photography. ${ }^{31}$ However, no matter 
how diverse Brazil's collection was planned to be, its agricultural and forestry products were the exhibits mostly praised by foreign visitors and experts. A review article published in the L'Exposition Universelle Illustrée discouraged the Empire's attempt at displaying manufactured objects: 'We cannot deny that the true, useful and practical side of the Brazilian exhibition is not [with the leather goods, felt hats and fabrics], but with its so rich and varied products of the earth' ${ }^{32}$ Tellingly, more than half of the 106 medals awarded to Brazil were for extracted (e.g. wood) or cultivated goods (e.g. cotton). ${ }^{33}$

Not all Brazilian raw materials were ranked the same. John Miers, a British scientific expert hired to judge Brazil's mineral collections thought them poor, except for a few coal specimens described as 'more precious than [the] famous [Brazilian] gold mines'. ${ }^{34}$ Not surprisingly, the British scientist suggested that 'for the economic development of Brazil' the coal should be exploited by 'an international enterprise, preferably an English one'. ${ }^{35}$ Miers' employment by the Brazilian Empire and his opportunistic advice that favoured British interests demonstrate that the strategy of showing in Paris Brazilian 'products of first necessity for the European commerce and industries' formed a convenient synergy between Brazil's offer of raw materials and Europe's industrial demand. ${ }^{36}$ This synergy is materialised in an exhibit that stirred Miers' pragmatic mind and inquisitive eye, an exhibit that 'exceeded any other of the same type': a large collection of tropical woods from the Amazon forest. ${ }^{37}$

Commissioner Villeneuve offered a detailed description of this wood display to the Brazilian emperor:

\footnotetext{
Palm-tree leaves indicate a new Brazilian room, this is the woods' room; all samples are gathered in a high and large pyramid disposed in such a way as to show to the public the horizontal, vertical and diagonal sections of the trunks. Around this room, runs a decoration that represents a virgin forest, under a dome formed by the lofty branches of a tree, behind of which one can see the blue and transparent sky. This decoration, owed to the skilled brush of one of the main stage designers of the Parisian Opéra, M. [Auguste] Rubé, immediately earned a good reputation in the Champs de Mars, and the virgin forest was soon one of the most visited places of the exhibition, being reproduced in illustrated magazines, and mentioned in all newspapers and journals. 38
} 
The 'virgin forest display', an epithet given by the French press, allowed visitors to walk around the centrepiece (Figure 5). ${ }^{39}$ They could inspect this imposing collection and measure their bodies against the Amazon trees. The spectacular painted setting gave visitors an immediate feel of the bounty of this legendary and distant forest. The Brazilian wood display, though, brought the forest near. In fact, before the opening of the Exposition Universelle Brazilian commissioners granted permission to foreign carpenters who worked on site to handle those rare specimens of tropical wood, which have never seen before. ${ }^{40}$

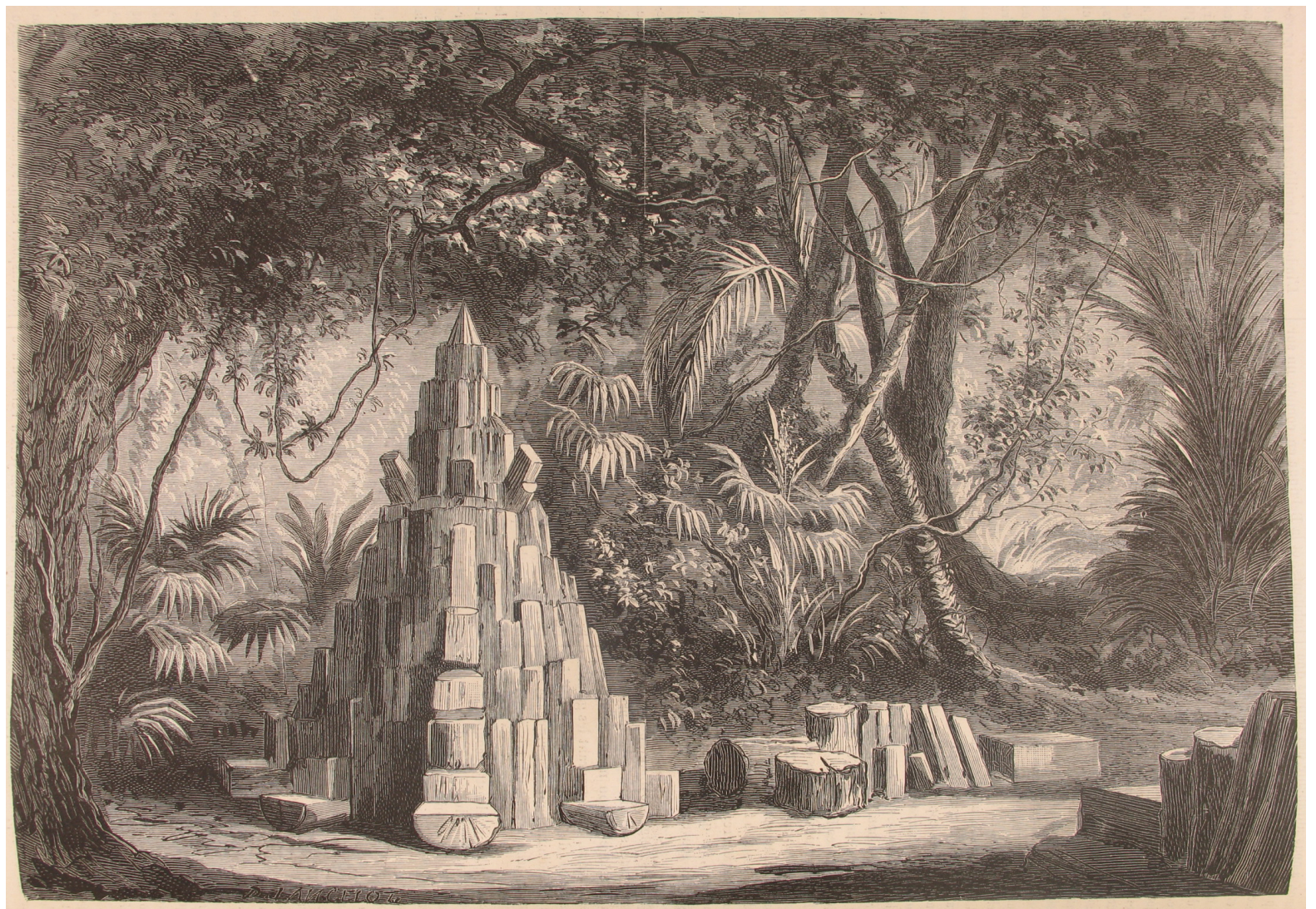

Figure 5. Lithograph depicting the 'virgin forest' or the Brazilian display of tropical woods exhibited at the Exposition Universelle, Paris, 1867. F. Ducuing, L'Exposition Universelle de 1867 Illustrée, Ch. Lahure, Paris, 1867. Author's own photograph 
Contrary to contemporary exhibitionary conventions, the Brazilian wood was not encapsulated in vitrines. Vitrines that are to scholar Francisco Foot Hardman 'the most cynical way in which luxury shows itself, signalling at the same time its price and its owner. It is an exhibitionism that also means a radical mode of separation'. ${ }^{41}$ The open display, instead, promised and delivered reunion, close contact, and demystification. Through a symmetrical, structured and ordered design, the public was offered an intelligible glimpse of the Amazon's forestry riches. Thus, Brazilian commissioners demonstrated they knew their resources and how to manage them. Now, so could Europeans.

The Amazon wood display could not have been more timely and strategic in terms of its economic relevance for the Brazilian Empire and for Europe. In 1866, an official decree opened the Amazon River to international navigation, facilitating and promoting the exploitation of natural resources by foreign companies. ${ }^{42}$ This decision was met with excitement and relief by European industrialists, as this remarkable quote from a French exhibition report reveals:

\begin{abstract}
The Brazilian government has understood all the advantages that the international commerce will be able to [...] take of its forestry riches, and a liberal decree has just opened to all countries' flags this ocean of fresh water we call Amazon. There, the gigantic trees offer themselves [...] for those who want to bring them down, and the river itself furnishes the easiest and less costly means of transport until the port of Para, which is the great Brazilian gateway open to the sea, it is, to the old continent. It is a relieving thought that industry will not stop for lack of nourishment, and that it can follow without fear this route of progress of which this exhibition is a striking manifestation. ${ }^{43}$
\end{abstract}

This quote discloses how by the late 1860s European industrial development was beginning to depend on raw materials from abroad. This sort of mutual dependency, however, is rarely addressed by the literature on exhibitions or the design history scholarship. The above quote is extraordinarily rich in what Louise Guenther calls 'the tone of gendered desire that operated in informal-imperial relations' as those established between Brazil and Britain at that time. ${ }^{44}$ For Guenther, penetration, expansion, and decline are imperialist metaphors 
that attest to a 'intellectual tendency [that] favour[s] vital interests of male bodies', a language bias that 'has had the effect of distorting historical understanding'. ${ }^{45}$ Guenther admits the improbability, for example, of naming the presence of British merchants and investors in nineteenth-century Brazil a process of 'invagination of Britain by Brazilians', despite the accepted penetration metaphor. 'Yet', she argues, 'even this would suggest different ways of asking just what happened, how and why' ${ }^{46}$ Guenther concludes that Brazil's role in relation to Britain was more active than the conventionalized male-gendered terminology allows us to think. ${ }^{47}$

In Das Capital, published as the 1867 Exposition Universelle unfolded, Marx proposed that a 'thing can be a use-value though it has no value. That is the case when its utility to mankind is not the outcome of labour' ${ }^{48}$ Instances were given: 'air, virgin soil, prairie, primeval forests' ${ }^{49}$ Marx continues to propose how these natural materials were reconceptualised as natural resources, ascribed value and commodified: 'To produce commodities he [a worker] must produce, not use-values merely, but use-values for others social use-values. [...] To become a commodity, a product must pass by way of exchange into the hands of the other person for whom it has a use-value'. ${ }^{50}$

Marx's formulation of a political economic model - whether descriptive or prescriptive - resonated with contemporary Brazilian exhibitionary efforts on various levels. The gendering of nature and labour were crucial strategies deployed in the conceptualisation and commodification of Brazilian nature in the Exposition Universelle, as just seen. The gendering of nature and labour are also found in Marx's 1867 explanatory model for capitalism:

The use-values coat, linen, commodities in general, are compounded of two elements, matter and labour. [...] In the process of production, man can only work as nature works by changing the forms of matter. [...] We see, then, that labour is not the only source of the use-values it produces, is not the only source of material wealth. As William Petty phrases it, while labour is the father of material wealth, the earth is its mother. ${ }^{51}$ 
Marx suggests a conceptual identification between femaleness, nature and passiveness on the one side, and maleness, labour and action on the other. 'Matter', in Marx, awaits labour and we can see this separation operating in the core of capitalist thinking. After labourer-fathers transform earth-mothers' natural materials into natural resources, the end result - commodities - spin out of control:

\begin{abstract}
At the first glance, a commodity seems a commonplace sort of thing, one easily understood. Analysis shows, however, that it is a very queer thing indeed, full of metaphysical subtleties and theological whimsies. In so far as it is a use-value, there is nothing mysterious about it - whether we regard it as something whose natural properties enable it to satisfy human wants, or as something which only acquires such properties as the outcome of human labour. It is obvious that man, by his activity, modifies the forms of natural substances so as to make them useful to himself. For instance, the form of wood is altered when we make a table of it. None the less, the table is still wood, an ordinary, palpable thing. But as soon as it presents itself as a commodity it is transformed into a thing which is transcendental as well as palpable. It stands with its feet solidly planted on the floor: but at the same time, over against all commodities, it stands on its head; and in that wooden head it forms crotchets far stranger than table-turning ever was. ${ }^{52}$
\end{abstract}

Above, Marx wonders about these transformations that so distinctively characterise human endeavour: the transformation of natural materials into useful things for exchange, or commodities. Wood as a natural substance is easily comprehensible for Marx. It has material properties; it is solid, palpable, it is 'given' by nature. After the process of transformation by labour, Marx concedes, the 'form' of the wood is altered. Labour (and design, as a productive act underpinned by forethought) transforms the wood's use-value into exchange value by turning it into a table. What makes the table eventually 'stand on its head' is its relation to other commodities. In a system of commodity exchange where commodities spin out of control Marx's table is no longer a simple, palpable form made of wood. Its solidity melts into the air of exchange relations; the table transcends all previous properties and acquires new ones.

At the 1867 Exposition Universelle, the naming of the Brazilian wood display 'virgin forest' perfectly echoed Marx's conflation of nature and the feminine. It also corroborated Guenther's idea of gendered desire, an idea clearly expressed by the tone employed in the 
French exhibition report to describe their ambition in the Amazon forest. In the report, the male-gendered, allegedly active players coincide with governmental and commercial interests, both Brazilian (the decree that opened the Amazon) and international (the commerce that will take advantage of forestry and bring trees down). The female-gendered, allegedly passive subjects concur with nature: the great provider of nourishment for industries, the trees who offer themselves, and the river that furnishes transport. The French report discloses a European desire to 'discover' Brazil's female-gendered nature, and rejoices in the nation's openness to the old continent. Brazilian commissioners, subscribing to this gendered conceptualisation of nature, asserted a male-gendered position for themselves. Undoubtedly, this assertion of maleness can also be read in relation to Portugal's presence at the same exhibition and Brazil's recent postcolonial status in 1867. Politically, Brazilian commissioners used the Exposition Universelle to demonstrate their autonomy in controlling Brazil's own raw material output, a newly acquired imperial tone not dissimilar to that employed by Prussians in the same exhibition. ${ }^{53}$ Moreover, Brazilian commissioners ordered their raw materials in a sophisticated display turning them into 'national resources' known and visible to potential business partners abroad. Brazilian commissioners offered these resources in a way European industrialists wanted them: abundantly and easily accessible.

The impressive staging of Brazilian wood - turned into timber (a natural resource) and turned into a virgin forest (a national resource) - also spoke to a European consciousness formed by interests other than commercial ones. In her comprehensive analysis of the representations of tropical nature, Nancy Les Stepan affirms that tropicality is 'an imaginative construct' constituted by a persistent and misleading 'visual grammar' that evolved in time, especially after European Enlightenment. ${ }^{54}$ Representations of Brazil as a tropical landscape which have been unstable and often required 'periodic reinvestment in times of change and challenge' - date back at least to 1660 when Franz Post's paintings of the New Dutch World 
followed European landscape conventions 'with little of the exotic in them'. ${ }^{55}$ Eighteenthcentury colonial expansion and scientific global circumnavigation 'provided a model for writing about and viewing the tropics that influenced naturalists and artists' for decades to come with the fundamental help of Alexander von Humboldt. ${ }^{56}$ This model included exaggerating the differences between tropical and temperate climates and vegetations (not to mention further differentiation of peoples and races). It described the tropics as primeval, purer, abundant, sinister, untamed, sublime, and/or untouched. In short, these writings and subsequent visual representations transformed the tropics into a foreign other, an exotic. If the nineteenth century was 'the tropical century par excellence', as stated by Stepan, the 1860s marked the culmination of the visual tropicalisation of Brazil, I argue. ${ }^{57}$ ' $[\mathrm{T}]$ he distinction between what was tropical and what was not took on new material, representational and symbolic meanings' also through the commodification of raw materials promoted at the Exposition Universelle. ${ }^{58}$ The virgin forest display, thus, can be understood as one of the moments when tropicality was compounded.

A question remains though: why did Brazilian commissioners reproduce Europeanised tropicality in their self-representation in Paris? Firstly, it is important to highlight that this reproduction was not without a degree of 'appropriation and re-elaboration' of the established pictorial and verbal tropical repertoire. As discussed above, the European conceptualisation of tropicality was not necessarily a positive one. Exhibits like the virgin forest display, I argue, had the power to destabilise the negative aspects of this established tropical visual repertoire whilst making use of it. Brazilian exhibition commissioners undermined established negative tropicality by showing how a civilisation was being formed in the tropics by showing possession and control over the bounty of the Amazon forest. This display projected an exotic but also a progressive, civilised image of Brazil abroad. 
The design of the tropical wood display also responded to a scientised and utilitarian conceptualisation of nature current at that time. Brazilian commissioner José Saldanha da Gama, a prolific botanist, directly impacted the design of the virgin forest display albeit not working as a designer in any way. ${ }^{59}$ In his studies, mostly published and distributed at international exhibitions, Gama systematically analysed, described, measured, and classified tropical woods similar to those employed in the virgin forest display. ${ }^{60}$ He tested their resistance, flexibility and density, and shared his findings with the Société Botanique (Botanical Society) in Paris. ${ }^{61}$ In 1867 , to argue for a more effective display of Brazilian raw materials Gama traced a genealogy of how Brazil had displayed wood in previous festivals. According to Gama, the Brazilian Empire had failed to promote its forestry riches in Paris in 1855 when 'products of an indigenous palm-tree' were shown scantly and enclosed in vitrines, this is, away from touch. ${ }^{62}$ Gama also condemned the presentation of Brazilian wood in the 1862 London exhibition for its lack of scientific information. He criticised their inappropriate display in small, varnished blocks that did not enhance the material properties of tropical wood or 'attract the eyes' of visitors. ${ }^{63}$ To compensate for these previous fail attempts, Gama proposed something quite different in 1867, a 'revenge' in his own words. ${ }^{64}$ This revenge took the form of the virgin forest display, its tree trunks arranged in sections specifically cut to reveal rawness, the woods' material qualities and to flaunt their usefulness. Thus, following Gama's scientised and utilitarian call for a material-driven design, more than 200 tropical wood specimens were shown in the open, as earth-mothers' natural materials awaiting European industrialists, or labourer-fathers. ${ }^{65}$ The trunks were exposed in their entirety - bark, core, grain - to prove their varied application in medicine, art, or the naval industries. Vitrines, finishing or varnishes were abolished as trappings for luxury products; they detracted from showing the texture of the bark or the direction of the grain. Brazilian woods, Gama concluded, had to be exhibited in their raw and profitable state. ${ }^{66}$ 
Table and wood; cooked and raw. Claude Lévi-Strauss' value binaries 'the raw and the cooked' form an apt framework to understand Gama's strategies in conceptualising and displaying raw materials the way Brazil did. In a study that spanned from his 1930s fieldwork in Brazil to the publication of the Mythologiques trilogy in the 1970s, Lévi-Strauss established that Amerindian myths were relational. ${ }^{67}$ The several orally transmitted Amerindian myths examined by Lévi-Strauss travelled over hundreds of years through numerous indigenous tribes and their content changed along the way. But despite these changes some mythic structures remained and it was the structural quality whereby these myths were transmitted that interested Lévi-Strauss.

One of his major contributions to an understanding of how humans structure their thinking was by observing that many myths 'refer directly or indirectly to the invention of fire and, therefore, of cooking, ${ }^{68}$ By possessing fire, humans could, according to mythological construction, protect and separate themselves from animals. Humans became predators and not prey; they could cook food while animals ate raw. Cooking, therefore, mediated human evolution from a departing natural state towards the development of culture. In Lévi-Strauss' investigations into the complex relationship between nature and culture, the 'raw' was equated with the natural, untouched, and untransformed world. The 'cooked' meant that which was cultural, had been produced or transformed by humans. However, while the raw and the cooked can be seen as atavistic categories of classification and thought in structural analysis they do not simply oppose each other when employed in the present design historical scrutiny. Raw, therefore, is a useful concept for this study of raw materials' displays in so far as it stands in a dialogical relation to its counterpart, the cooked (i.e. the manufactured). These concepts do not stand in a conflicting interaction: the cooked postulates the raw as Marx's table postulates the wood. 


\section{Putting nature in our official past, present and future (final thoughts)}

In this article I have discussed the contexts in place and the mechanisms employed in manufacturing an idea of the 'raw' in design pageantries. Lévi-Strauss' work on understanding the dialogical relationship between the raw and the cooked allows us to extend this analysis to the ways whereby designed things sit in a dialogical relation to their raw materials. The 'raw', as seen in the virgin forest display, was a construct devised and employed in an exhibition precisely for its potency to project other constructs - manufactured objects, for example - as cooked. By definition, though, nothing designed is raw. Thus, not even the tropical woods that made up the virgin forest display were raw after all; they have been manufactured into designed things themselves.

Marx's gendering of nature and his discussion of use- and exchange-value allow us to place this dialogical relation between the raw and the manufactured back at the core of capitalist operations, and help us understand why designing a display to look raw might have been the most appropriate form of commodifying these materials. In 1867, Marx posited that 'none the less, the table is still wood, an ordinary, palpable thing ${ }^{69}$ Can we still affirm, after almost 150 years of historical change when commodity metaphysics have become less subtle, that a designed object (table) is still its material (wood)? The plot has thickened for historical materialism accounts since synthetic materials and an increasingly complex system of commodity exchange have widened the gap between materials and designed outcomes. Even in times contemporary to Marx's assertion we observe a far greater complex relationship between natural materials and designed objects: the woods from the virgin forest display were turned into a commodity even before they could be turned into a table. That display was specifically designed to make the material properties of its original matter (wood) profitable, and it was this design act that commodified the wood, paradoxically, presented at the Exposition Universelle as a raw, uncooked, 'natural' material. This design act was not only 
manifested in the making of the display to look 'raw' but it was made possible due to the display's relation to the myriad of other 'manufactured' commodities shown in that design pageantry. Likewise, the conceptualisation of Brazilian tropical nature changed from its iteration as wild and antithetical to culture and civilization into a commercially exploitable possession. Its exploitation became a marker of civilization in the tropics.

In this article I have also argued that environmental issues - be them raw material exploitation, deforestation or social inequality - has to be understood as a cultural problem. This is not to say that nature itself should be subsumed to culture; but it is to say that there is an idea of nature that is culturally constructed, and therefore can be deconstructed. If this hypothesis holds up, design and designers would be endowed with the ability of not simply solving particular and local environmental problems but also of interfering in a larger system of values that may change the complex relationship between nature and culture with the ultimate goal of projecting sustainable presents and futures.

Finally, I also wish to contend that once raw materials become more prominent in studies of exhibitions in particular and in design history more generally, key concerns from environmental histories studies will be brought to the fore. The understanding of how design plays a central role in shaping the system of values upon which culture and the idea of nature are predicated, or how we may render nature a level of agency usually conceded to social and cultural processes might be some of these concerns. 


\section{Figure captions}

Figure 1. Lithographic drawing depicting architectural Orientalism and French colonies at the Exposition Universelle, Paris, 1867. Grand Album de L'Exposition Universelle, 1867: 150 Dessins Par Les Premiers Artistes de la France et de l'Etranger, Michel Lévy Freres, Paris, 1868. Author's own photograph

Figure 2. Lithographic drawing depicting the display of timber from Canada exhibited at the British colonial court, Exposition Universelle, Paris, 1867. Grand Album de L'Exposition Universelle, 1867: 150 Dessins Par Les Premiers Artistes de la France et de l'Etranger, Michel Lévy Freres, Paris, 1868. Author's own photograph

Figure 3. Lithographic drawing depicting the Krupp Cannon exhibited by Prussia at the Exposition Universelle, Paris. Grand Album de L'Exposition Universelle, 1867: 150 Dessins Par Les Premiers Artistes de la France et de l'Etranger, Michel Lévy Freres, Paris, 1868. Author's own photograph

Figure 4. Lithographic drawing depicting Prussia's display of salt and charcoal at the Exposition Universelle, Paris, 1867. Grand Album de L'Exposition Universelle, 1867: 150 Dessins Par Les Premiers Artistes de la France et de l'Etranger, Michel Lévy Freres, Paris, 1868. Author's own photograph

Figure 5. Lithograph depicting the 'virgin forest' or the Brazilian display of tropical woods exhibited at the Exposition Universelle, Paris, 1867. F. Ducuing, L'Exposition Universelle de 1867 Illustrée, Ch. Lahure, Paris, 1867. Author's own photograph

\footnotetext{
${ }^{1}$ T. Ingold, 'Materials against Materiality', Archaeological Dialogues, vol.14, no.1, pp.1-16. For a critique of the 'glaringly white spot' of environmental history on the design historical map see K. Fallan, 'Our Common Future: Joining Forces for Histories of Sustainable Design', Tecnoscienza, vol.5, no.2, pp.13-44.

${ }^{2}$ This trend can be exemplified by Paul Greenhalgh's distinction between the prefabricated and the massproduced in exhibitions without including the status of raw materials in these festivals: P. Greenhalgh, Ephemeral Vistas: A History of the Expositions Universelles, Great Exhibitions and World's Fairs, 1851-1939, Manchester University Press, Manchester, 1988, ch.6. ${ }^{3}$ W. Plum, World Exhibitions in the Nineteenth Century: Pageants of Social and Cultural Change, Friedrich-
Ebert Stiftung, Bonn-Bad Godesburg, 1977.

${ }^{4}$ International Exhibitions have been mostly studied through the theoretical prisms of national identity formation, imperialism and colonialism, spectacle and visuality, and ephemerality. Analyses tend to centre on displays of technology, fine art, science, native and colonised peoples, designed objects or architectural feats. See, among others: J. A. Auerbach and P. H. Hoffenberg (eds), Britain, the Empire, and the World at the Great Exhibition of 1851, Ashgate, Aldershot, 2008; D. Bhagat, 'Performing White South-African Identity Through International and Empire Exhibitions', Global Design History, G. Adamson, G. Riello and S. Teasley (eds), Routledge, London, 2011; Z. Çelik, Displaying the Orient: Architecture of Islam at Nineteenth-Century World's Fairs, University of California Press, Berkeley, 1992; A.C.T. Geppert, Fleeting Cities: Imperial Expositions in Fin-de-Siècle Europe, New York, Palrave Macmillan, 2009; A.L. Heizer, 'Os Instrumentos Científicos e as Exposições do Século XIX’, Ciência, Civilização e Império nos Trópicos, MAST, Rio de Janeiro, 2001; L. Purbrick (ed), The Great Exhibition of 1851: New Interdisciplinary Essays, Manchester University Press, Manchester, 2001; R.W. Rydell and N. Gwinn (eds), Fair Representations: World's Fairs and the Modern World, VU University Press, Amsterdam,
} 
1994; P. Mainardi, Art and Politics of the Second Empire: The Universal Expositions of 1855 and 1867, New Haven, Yale University Press, 1987.

\author{
${ }^{5}$ J. R. McNeill, J. A. Pádua, M. Rangarajan (eds), Environmental History: As If Nature Existed, Oxford \\ University Press, Oxford, 2010, p.5. \\ ${ }^{6}$ For instance, C. Leal, J.A. Pádua and J. Soluri (eds), 'New Environmental Histories of Latin America and the \\ Caribbean', Rachel Carson Centre Perspectives, vol.7, 2013; S. W. Miller, Environmental History of Latin \\ America, Cambridge University Press, Cambridge, 2007; J. R. McNeill, J. A. Pádua, M. Rangarajan (eds), op. \\ cit.
}

${ }^{7}$ See also William Cronon's 'The Trouble With Wilderness, or, Getting Back to the Wrong Nature', William Cronon (ed) Uncommon Ground: Rethinking the Human Place in Nature, W. W. Norton \& Co., New York, 1995, pp.69-90.

${ }^{8}$ E. G. K. Melville, A Plague of Sheep: Environmental Consequences of the Conquest of Mexico, Cambridge University Press, Cambridge, 1994.

${ }^{9}$ Miller, op. cit., p.5.

${ }^{10}$ Key works on the subject include: J. Andermann, 'Tournaments of Value: Argentina and Brazil in the Age of Exhibitions', Journal of Material Culture, vol.14, pp.333-63; H. Barbuy, A Exposição Universal de 1889 em Paris: Visão e Representação na Sociedade Industrial, Loyola, São Paulo, 1999; N. C. Elkin, 'Promoting a New Brazil: National Expositions and Images Of Modernity, 1861-1922', PhD thesis, Rutgers University, 1999; F. F. Hardman, Trem Fantasma: A Ferrovia Maderia-Mamoré e a Modernidade na Selva, Companhia das Letras, São Paulo, 1988; M. Kuhlmann Junior, As Grandes Festas Didáticas: A Educação Brasileira e as Exposições Internacionais, 1862-1922, EDUSF, Bragança Paulista, 2001; S. J. Pesavento, Exposições Universais: Espetáculos da Modernidade no Século XIX, Hucitec, São Paulo, 1997; L. Rezende, 'Of Coffee, Nature and Exclusion: Designing Brazilian National Identity at International Exhibitions, 1867 \& 1904', G. Lees-Maffei and K. Fallan (eds), Designing Worlds: National Design Histories in the Age of Globalization, Berghahn, Oxford, 2016; L. Rezende, 'The Artifice of Nature and the Naturalisation of the State at the 1922 Rio de Janeiro International Exhibition', M Filipova, Cultures of Exhibitions, Ashgate, London, 2015; S. Schuster, 'The "Brazilian Native" on Display: Indianist Artwork and Ethnographic Exhibits at the World's Fairs, 1862-1889', RIHA Journal, no.127, pp.21-43; S. Schuster, "The Pursuit of Human Perfection": Brazil at the Vienna Universal Exhibition of 1873', Historia Crítica, no.55, pp.45-71, and S. Schuster, 'Envisioning a "Whitened" Brazil: Photography and Slavery at the World's Fairs, 1862-1889', Estudios Interdisciplinarios de América Latina y el Caribe, vol.26, no.2, pp.17-41; L. M. Schwarcz, 'Os Trópicos como Espetáculo: a Participação Brasileira nas Exposições Universais de Finais do Século XIX’, S. B. Gonzales and J. Andermann (eds), Galerías del Progreso: Museos, Exposiciones y Cultura Visual en América Latina, Beatriz Viterbo, Rosário, 2006, pp.195-220; M. I. Turazzi, Poses e Trejeitos: A Fotografia e as Exposições Universais na Era do Espetáculo, 1839-1889, Rocco \& Funarte, Rio de Janeiro, 1995.

${ }^{11}$ See Rezende, 'Of Coffee, Nature and Exclusion', op. cit. Only recently crucial work is being done on race and displays depicting slavery and native peoples from Brazil, at home and abroad: S. Schuster, 'The "Brazilian Native” on Display', op. cit.; S. Schuster, “"The Pursuit of Human Perfection””, op. cit., and S. Schuster, 'Envisioning a "Whitened" Brazil', op. cit.

${ }^{12}$ See Rezende, 'Of Coffee, Nature and Exclusion', op. cit., and L. Rezende, 'The Raw and the Manufactured: Brazilian Modernity and National Identity as Projected in International Exhibitions (1862-1922)', PhD Thesis, Royal College of Art, 2010.

${ }^{13}$ W. Benjamin, The Arcades Project, Harvard University Press, Cambridge, MA and London, 2002, p.7.

${ }^{14}$ The Empire of Brazil at the Paris International Exhibition of 1867, E. \& H. Laemmert, Rio de Janeiro, 1867, $\mathrm{s} / \mathrm{p}$.

${ }^{15}$ Greenhalgh, op. cit., p.33.

${ }^{16}$ P. v. Wesemael, Architecture of Instruction and Delight: A Socio-Historical Analysis of World Exhibitions as a Didactic Phenomenon, 1798-1851-1970, 010 Publishers, Rotterdam, 2001, ch.4; For Latin American nations participation in exhibitions see: A. Fernández-Bravo, 'Ambivalent Argentina: Nationalism, Exoticism, and Latin Americanism at the 1889 Paris Universal Exposition', Nepantla: Views from South, vol.2, pp.115-139; S. B. Gonzales and J. Andermann (eds), Galerías del Progreso: Museos, Exposiciones y Cultura Visual en América Latina, Beatriz Viterbo, Rosário, 2006; B.G. Stephan, 'Showcases of Consumption: Historical Panoramas and 
Universal Expositions', Beyond Imagined Communities: Reading and Writing the Nation in Nineteenth-Century Latin America, S. Castro-Klaren and J.C. Chasteen (eds), John Hopkins University Press, Baltimore and London, 2003, pp.225-38; M. Tenorio-Trillo, Mexico at the World's Fairs: Crafting a Modern Nation, California University Press, Berkeley, 1996, and M.A, Uslenghi, Images of Modernity: Latin American Culture and Nineteenth-century Universal Exhibitions, New York University, New York, 2007.

${ }^{17}$ Greenhalgh, op. cit., pp.64-65, 85.

${ }^{18}$ J. Allwood, The Great Exhibitions: 150 Years, Exhibition Consultants, London, 2001, p. 31; Pesavento, op. cit., pp.20 and 117.

${ }^{19}$ Benjamin, op. cit, p.7.

${ }^{20}$ Ibid., pp.7-8.

${ }^{21}$ Pesavento, op. cit., p.120.

${ }^{22}$ Ibid., p. 120.

${ }^{23}$ Greenhalgh, op. cit., pp.145-47.

${ }^{24}$ Allwood, op. cit., p.32.

${ }^{25}$ Greenhalgh, op. cit., p.20.

${ }^{26}$ Greenhalgh, op. cit., p.20.

${ }^{27}$ J. C. de Villeneuve (ed), Relatório Sobre a Exposição Universal de 1867, Typographia de Julio Claye, Paris, 1868 , p. xli.

${ }^{28}$ Pesavento, op. cit., p.127.

${ }^{29}$ P. v. Wesemael, op. cit., p.293.

${ }^{30}$ Ibid., p.293.

${ }^{31}$ Villeneuve (ed), op. cit., p.xliii.

${ }^{32}$ F. Ducuing (ed), L'Exposition Universelle de 1867 Illustrée, Imprimerie Générale de Ch. Lahure, Paris, 1867 , p.391.

${ }^{33}$ Villeneuve, op. cit., p.cxi.

${ }^{34}$ J. Miers, 'O Brazil na Exposição Universal de 1867 em Paris’ in Villeneuve (ed), Relatório, pp.589-91.

${ }^{35}$ Ibid., pp.589-91.

${ }^{36}$ Villeneuve, op. cit., p.xlii.

${ }^{37}$ Miers, op. cit., p.492. Information is scant about the wood extraction, its transportation to Paris, the agents behind transactions and shipment, and the eventual designing of the display. Further archival research may reveal aspects of these negotiations and contribute to a more in-depth understanding of how this collection was amassed.

${ }^{38}$ Villeneuve, op. cit., p.xlii. Original emphasis.

${ }^{39}$ Ibid., p.xlii.

${ }^{40}$ Ibid., p.xxxix.

${ }^{41}$ F. F. Hardman, op. cit., p.49.

${ }^{42}$ Miers, op. cit., p.492; Turazzi, op. cit., p.135. The Amazon River was 'opened' by the Decree 3.749, $07 / 12 / 1866$

${ }^{43}$ R. Ferrère, 'La Forêt Vierge du Brésil' in Ducuin, op. cit., p.278 (author's translation). 
${ }^{44}$ L. Guenther, 'The Artful Seductions of Informal Empire', Informal Empire in Latin America: Culture, Commerce and Capital, Blackwel, Oxford, 2008, p.209.

${ }^{45}$ Ibid., p.209.

${ }^{46}$ Ibid., pp.209-10.

${ }^{47}$ Ibid., p.228.

${ }^{48}$ K. Marx, Capital, vol. 1, Dent, London, 1972, p.9.

${ }^{49}$ Ibid., p.9.

${ }^{50}$ Ibid., p.9. Original emphasis.

${ }^{51}$ Ibid., p. 12.

52 Ibid., pp.43-44.

${ }^{53}$ Manuel de Araujo Porto Alegre, in Villeneuve (ed), op. cit., pp.456-7.

${ }^{54}$ N. L. Stepan, Picturing Tropical Nature, Reaktion, London, 2001, pp.11-13. Stepan borrows the term tropicality from David Arnold 'to indicate the constructed or discursive representation of the tropics in modern geography', p.13.

${ }^{55}$ Ibid., p.19 and 21.

${ }^{56}$ Ibid., p.25.

${ }^{57}$ Ibid., p.31.

${ }^{58}$ Ibid., p. 17.

${ }^{59}$ José de Saldanha da Gama (1839-n/d) contributed to several Brazilian international exhibitions. He was linked to the Instituto Politécnico (Polytechnic Institute), the Escola Central (Central School), the Instituto Imperial Fluminense de Agricultura (Fluminense Imperial Institute for Agriculture, IIFA), among others, and affiliated to the Société Botanique de France (French Botanical Society) and the Société Linnéenne de Paris (Linnaean Society of Paris).

${ }^{60}$ Gama researched, published and translated over twenty studies on botany, wood and vegetable fibres, including Breve Noticia Sobre a Collecção das Madeiras do Brasil Apresentada na Exposição Internacional de 1867, Typographia Nacional, Rio de Janeiro, 1867; Classement Botanique des Plantes Alimentaires du Brésil, Imprimerie de E. Martinet, Paris, 1867; Travaux au sujet des Produits du Brésil qui Sont a l'Exposition Universelle de Paris en 1867, Imprimerie de E. Brière, Paris, 1867; Quelques Mots sur le Boi du Brésil qui Doivent Figurer a l'Exposition Universelle de 1867, Imprimerie de E. Martinet, Paris, 1867.

${ }^{61}$ Gama, Quelques mots, op. cit.

${ }^{62}$ Ibid., pp.3-4.

${ }^{63}$ Ibid., p.3.

${ }^{64}$ Ibid., p.4.

${ }^{65}$ Information about the authorship of the display is inconclusive but through Gama's account we can deduce his participation in it. Brazilian commissioners' reports emphasise the final aspect of the display and overlook information about its making process, creators, or exchanges between commissioners and scientists.

${ }^{66}$ Gama, Breve Noticia, op. cit.

${ }^{67}$ C. Lévi-Strauss, The Raw and the Cooked. Introduction to a Science of Mythology I, Cape, London, 1970.

${ }^{68}$ R. de B. Laraia, 'Claude Lévi-Strauss, Quatro Décadas Depois: As Mitológicas', Revista Brasileira de Ciências Sociais, vol. 21, pp.167-69.

${ }^{69}$ Marx, op. cit., pp.43-44. 